\title{
Dawid Niemczycki
}

\section{THE RIGHT TO SAY GOODBYE AND PERMISSION TO LEAVE A PENITENTIARY FACILITY}

The imprisonment and detention on remand bring detachment from the family, home and local environment. Therefore, several basic questions arise, among which the key is whether prisoners in this forced isolation are deprived of the right to say goodbye to those close to them? In addition, the issue of the subjective scope of the right to say goodbye arises, i.e. the possibility of indicating whether all prisoners, including the most dangerous, can exercise this right. Furthermore, how to precisely define the boundary of "closest people"? Do people living in informal relationships fall into this category? Finally, does the current laws allow for effective redress? The above questions do not exhaust the complexity of this issue. In this article many more will be laid down.

Considerations should begin with the indication that the right to say goodbye is inseparably connected with the issue of contacts of prisoners with the outside world. However, as pointed out by J. Leaute, a professor at the University of Paris, the problem of "penitentiary paradox" is constantly present, which relies on the fact that the search for improvement of the convict takes place by isolating him/her from society, which brings criminals closer together [Śliwowski 1984, 17]. It is widely known that isolation that forms part of a prison sentence may contribute to the deprivation of viscerogenic (related to the functioning of the body) needs as well as psychogenic needs

Dawid Niemczycki MSc, M.A., Ph.D. Student - Maria Curie-Skłodowska University in Lublin; ul. Jana Kasprowicza 119C/75, 01-949 Warszawa, Poland; e-mail: dawidniemczycki@o2.pl; https://orcid.org/0000-0001-8176-3066 
to psychosocial needs, which are limited to the greatest extent [Linowski $2001,125]$.

To come ahead of this problem since the Second World War there has been understanding that the extensive contacts with family and relatives are essential for the peaceful conduct of social rehabilitation and the future adaptation of the convict to life in the free [Wierzbicki 1984, 136]. Despite of this, there arises a problem of finding the "happy medium" enabling isolation of persons having conflict with the law on the one hand, and respect for their rights, in particular the right to respect for family life, on the other. All this proves that the problem raised in this article is still valid and requires a new look at it.

\section{THE GENESIS OF THE RIGHT TO SAY GOODBYE}

The origins of the right to say goodbye should be seen in the case law of the European Court of Human Rights ${ }^{1}$ in Strasbourg. At the same time, it is worth noting that initially the conviction was dominated by the view that the refusal to grant a pass to a prisoner in order to attend a funeral of a relative does not violate Art. 8 of the ECHR. ${ }^{2}$ However, over time - or more precisely - in 2002, the situation changed and the ground-breaking judgment in Ptoski vs Poland was completely different. ${ }^{3}$ It is worth noting that even in this judgment it was stated that Art. 8 of the ECHR does not guarantee a detainee's unconditional right to obtain a pass to attend a funeral of relatives, since it is for the national authorities to assess each application as to its essence.

Despite the above statement, the ECtHR emphasized that the refusals to grant a pass to attend the funerals of the applicant's parents were not "necessary in a democratic society" because they did not respond to the social demand demanded/required and were not proportionate to the justi-

\footnotetext{
${ }^{1}$ Henceforth cited as: ECtHR.

${ }^{2}$ European Convention on Human Rights (4.11.1950) [henceforth cited as: ECHR], https://www.echr.coe.int/Documents/Convention_ENG.pdf [accessed: 22.01.2020]. See judgment of the ECtHR of 25 November 1999 in the case of Marincola and Sestito vs Italy (application no. 42662/98), and judgment of 13 January 2000 in the case of Georgiou vs Greece (application no. 45138/98). Both judgments are unpublished.

${ }^{3}$ Judgment of the ECtHR of 12 November 2002 in the case of Ptoski vs Poland (application no. 26761/95), http://hudoc.echr.coe.int/eng?i=001-99120 [accessed: 22.01.2020].
} 
fied purpose for which they were undertaken. ${ }^{4}$ The Court further noted that the respondent State could refuse a permit only if there were compelling reasons and if an alternative solution could not be found - which is the granting of a permit with the assistance of the police. All this resulted in a violation of Art. 8 of the ECHR.

In subsequent years, the legal regulation, which was the basis for the decision issued in the case of Ptoski vs Poland, did not change, and subsequent cases began to appear before the Tribunal regarding the refusal to grant permission to attend the funeral of loved ones [Wedel-Domaradzka 2013, 277].

In the Krym vs Poland case, the applicant alleged that the refusal to grant him permission to attend his mother's funeral constituted degrading treatment contrary to Art. 3 of the ECHR and, in addition, in the applicant's opinion, also violated Art. 9 of the ECHR, because as a practicing Catholic he considered the funeral to be a "ritual."5 However, the ECtHR, not being obliged to provide the description provided by the applicant, transferred the complaint pursuant to Art. 8 of the ECHR. ${ }^{6}$ This case ended with a statement by the Polish government addressed to the ECtHR in which it considered that the refusal to allow the applicant permission to attend his mother's funeral was not in accordance with his right to respect for family life, as guaranteed in Art. 8 of the ECHR [ibid.].

In the case of Gustaw vs Poland, the applicant submitted that the refusal to attend his father's funeral constituted a violation not only of Art. 8 of the ECHR, but also Art. 7, 13 and 14 of the ECHR. ${ }^{7}$ However, the ECtHR pointed out that the circumstances of the case only indicate a violation of Art. 8 of the ECHR and due to the government's declaration regarding the compensation payment and the partial groundlessness of the complaint, the case was dismissed from the list [ibid., 278].

Also the case of Wiestaw Gil vs Poland ${ }^{8}$ it was argued that the refusal to grant the applicant permission to attend his father's funeral constituted

\footnotetext{
${ }^{4}$ Ibid., sect. 39 .

${ }^{5}$ Decision of the ECtHR of 7 October 2008 in the case of Krym vs Poland (complaint no. 26938/05), http://hudoc.echr.coe.int/eng?i=001-89178 [accessed: 22.01.2020].

${ }^{6}$ Ibid.

${ }^{7}$ Decision of the ECtHR of 13 November 2008 in the case of Gustaw vs Poland (complaint no. 39507/04), http://hudoc.echr.coe.int/eng?i=001-89930 [accessed: 22.01.2020].

${ }^{8}$ Decision of the ECtHR of 13 January 2009 in the case of Wiestaw Gil vs Poland (complaint no. 10251/03), http://hudoc.echr.coe.int/eng?i=001-91076 [accessed: 22.01.2020].
} 
a violation of Art. 8 of the ECHR, however, this case was not considered in substantive terms, as the Polish party sent a statement to the ECtHR containing a declaration of payment of damages and thus an amicable settlement of the case [ibid.].

The judgment of Czarnowski vs Poland ${ }^{9}$ should be also mentioned, where the applicant alleged that the refusal to grant him the occasional permission to leave the prison in order to attend his father's funeral was contrary to Art. 8 of the ECHR.

Although the final verdict in this case was identical as the decision in Ptoski vs Poland, it is worth noting that the Polish government questioned the validity of the complaint and pointed out that the applicant had not exhausted all available domestic legal remedies as he could appeal against the order and, secondly, he should have brought an action under Art. 24 in connection with Art. 448 of the Civil Code. ${ }^{10}$ However, the ECtHR pointed out that since it is the government which accuses the applicant of not exhausting the national route, it is necessary to prove that the legal measure indicated was effective and existing in theory and practice at the time in question, i.e. that it was available, its application could have brought the applicant satisfaction for the harm suffered and offered a real chance of a positive outcome for the applicant. The Court noted that the Government's allegations were limited to mere assertions and there is no reason to consider that an appeal against the order delivered to the applicant on the day of the funeral could be considered an effective remedy capable of guaranteeing him compensation for the harm suffered.

The right to say goodbye includes not only the possibility of attending the funeral of a loved one, but also grants the right to visit seriously ill relatives. The origins of this right should be seen in the case of Lind vs Russia ${ }^{11}$ regarding the refusal of a Dutch citizen in Russian detention to grant a permit to go to the Netherlands and visit his terminally ill father [Jakuszewicz 2015, 352]. Particularly important for the resolution of the case was the fact that the applicant's father had requested a euthanasia, which was considered positive, so the date of his death was determined, but

\footnotetext{
${ }^{9}$ Judgment of the ECtHR of 20 January 2009 in the case of Czarnowski vs Poland (complaint no. 28586/03), http://hudoc.echr.coe.int/eng?i=001-124454 [accessed: 22.01.2020].

${ }^{10}$ Ibid., sect. 16-17.

${ }^{11}$ Judgment of the ECtHR of 6 December 2007 in the case of Lind vs Russia (complaint no. 25664/05), http://hudoc.echr.coe.int/eng?i=001-83817 [accessed: 22.01.2020].
} 
nevertheless the Russian courts argued that there was a high probability that the applicant would not return to Russia or that he will have an unlawful influence on the course of the investigation. The applicant was only allowed to have a telephone conversation with his father at the expense of the Dutch embassy, with the proviso that the interview could only take place in Russian, although the applicant's father did not speak the language well, and after a minute of the conversation the connection was interrupted by the detention administration without giving any reason.

Decision of the ECtHR - despite finding a violation of Art. 8 of the ECHR - is not satisfying. The doctrine indicates that the process leading to making a decision in a given case must be reliable and take into account the interests of the individual, while the basis for the decision must be comprehensive and verifiable data on all aspects of the case [Nowicki 2017, 657]. On the one hand, the ECtHR emphasized that due to the special circumstances of the case, and in particular due to the fact that the applicant had the last opportunity to meet his father, there were strong humanitarian reasons justifying the need to examine his application with special diligence [Jakuszewicz 2015, 352]. On the other hand however, the ECtHR expressed its understanding of the authorities' concerns that the applicant might have slipped out of Russian jurisdiction. It was pointed out that pursuant to Art. 8 of the ECHR, an obligation arose for the applicant to be able to say goodbye to his dying father in another way, whereas a one-minute telephone conversation in a foreign language is not an appropriate form of contact.

In turn, in the case of Giszczak vs Poland ${ }^{12}$ the applicant stated that he was denied the opportunity to say goodbye to the dying daughter in the hospital, and his appeal against this decision was examined a month after his daughter's death, which was tantamount to "psychological torture." National authorities, justifying the refusal to grant a random pass, referred to the applicants' allegedly arrogant behaviour in a prison and the seriousness of the crime (incitement to murder), but the ECtHR found that this argument is not convincing, as granting permission to leave the prison under convoy could, in this situation, solve the problem, the failure to comply with these requirements violated the applicant's rights under Art. 8 of the ECHR.

${ }^{12}$ Judgment of the ECtHR of 29 November 2011 in the case of Giszczak vs Poland (complaint no. 40195/08), http://hudoc.echr.coe.int/eng?i=001-124700 [accessed: 22.01.2020]. 


\section{SUBJECT SCOPE}

Art. 47 of the Polish Constitution ${ }^{13}$ and Art. 8 of the ECHR show that the entity entitled to legal protection of private and family life is "everyone." The doctrine indicates that the term refers to the broadest classes of subjects of rights and obligations regulated at the Constitution level and includes in its scope both people, especially prisoners, as well as all other subjects of rights and obligations [Zubik 2007, 29]. M. Zubik emphasizes that despite of the fact that the Constitution in as many as 25 articles contained in Chapters I and II uses the concept of "everyone," some rights or freedoms may, by their very nature, only belong to natural persons [ibid., 30].

It is worth noting that church law also points to the aspect of freedom. According to the 1983 Code of Canon Law, ${ }^{14}$ lay faithful have the right to be granted the freedom all citizens have regarding matters of the temporal community (can. 227). It is claimed in the doctrine that the above norm specifies two fundamental rights: the right to religious freedom due from the civil society and the right to freedom in temporal matters due from the church community [Hervada 2011, 217].

\subsection{Beneficiaries of the right to say goodbye}

At the outset it should be noted that the right to say goodbye covers all natural persons. However, the greatest attention should be paid in particular to prisoners, because they are the most affected by barriers hindering - and sometimes preventing - the proper development of private and family life.

Art. 141a, para. 1 of the Executive Penal Code ${ }^{15}$ indicating the entity which is entitled - after meeting certain criteria/conditions - to obtain permission to leave the prison, uses the term "convicted." This concept - in accordance with Art. 242, para. 1 EPC - covers not only the person convicted by a final court judgment, but also the detainee who has been detained on remand and the perpetrator against whom a precautionary measure has been applied.

${ }^{13}$ Constitution of the Republic of Poland of 2 April 1997, Journal of Laws of 2009, No. 114, item 946.

${ }^{14}$ Codex Iuris Canonici auctoritate Ioannis Pauli PP. II promulgatus (25.01.1983), AAS 75 (1983), pars II, p. 1-317.

${ }^{15}$ Act of 6 June 1997, the Executive Penal Code, Journal of Laws of 2020, item 523 as amended [henceforth cited as: EPC]. 


\subsection{People deprived of the right to say goodbye}

Despite such a wide range of subjective right to say goodbye, it should be noted that there are certain groups of people who cannot exercise this right. In this case, the main value is to protect society against these people.

The first group consists of people placed in a relevant psychiatric institution. In the Order of the Supreme Court of 28 September 2006, it was indicated that the institution of permission to leave the prison (Art. 141a EPC) does not apply to the stay of a person placed in a relevant psychiatric institution (Art. $94 \mathrm{EPC}$ ). ${ }^{16}$

In turn, the second group of people, i.e. convicts posing a serious social threat - raises considerable differences in the doctrine. On one hand, it is pointed out that despite the fact that the provisions of Art. 141a EPC do not exclude the granting of permission to leave the prison to a convicted person who poses a serious social threat, it should be considered that this possibility is excluded. As S. Lelental emphasizes - this is due to the conditions in which the sentence is carried out against these convicts, pointing to Art. 88b EPC [Lelental 2017, 572]. On the other hand however, it is argued that according to the principle of lege non distinguente nec nostrum est distinguere, this category of convicts cannot be deprived of the right to say goodbye [Zgoliński 2018, 548].

\section{PERMISSION TO LEAVE THE PRISON AS THE ESSENCE OF THE RIGHT TO SAY GOODBYE}

The content of the right to say goodbye is based mainly on three legal acts: the Executive Penal Code, European Prison Rules ${ }^{17}$ and Nelson Mandela Rules. ${ }^{18}$

${ }^{16}$ Order of the Supreme Court of 28 September 2006, I KZP 23/06, LEX no. 201051.

${ }^{17}$ Recommendation of the Committee of Ministers to member states of the Council of Europe of 11 January 2006 on European Prison Rules [henceforth cited as: EPR], www.bip.sw.govspl/SiteCollectionDocuments/CZSW/prawaczl/document.pdf [accessed: 22.01.2020].

${ }^{18}$ UN General Assembly resolution of 7 October 2015 - United Nations Standard Minimum Rules for the treatment of prisoners (the so-called Nelson Mandela Rules) [henceforth cited as: NMR], https://www.rpo.govspl/pl/content/reguly-nelsona-mandeli [accessed: 22.01.2020]. 
On the ground of the Executive Penal Code the substantive legal basis for the right to say goodbye is Art. 141a, para. 1, which indicates that "the director of a prison may grant a convict permission to leave the prison under a convoy of a prison officer, a trustworthy person or alone, for a period not exceeding 5 days, to visit a seriously ill family member, attend a funeral of a family member and in other cases that are particularly important for the convict."

It is argued in the doctrine that the institution of a special permit to leave prison allows for taking into account during the sentence of special events in family life and other events particularly important for the convicted person [Zgoliński 2018, 547]. The current wording of the provision was aimed at adapting the national regulation to the European Prison Rules [Dąbkiewicz 2018, 637]. This provision also provides, inter alia, expression of respect for human dignity of convicted persons and humane treatment and minimizes the deprivation of convicts' needs connected with prison isolation [Zgoliński 2018, 547].

\subsection{Persons authorized to submit an application/to apply}

First of all, the circle of entities authorized to submit an application for a pass should be indicated. Although Art. 141a EPC does not explicitly state this, but bearing in mind the correlation of this provision with Art. 141 EPC, reference should be made to para. 3 of this provision, which provides that "relief shall be granted by the director of the penitentiary institution or a person authorized by him/her at the request of the convict or the closest person; or at the request of the superior of the convicted person." The above provision indicates the conclusive nature of the relief for which a considerable number of people may apply.

First, the convicted person can make such an application personally. Secondly, a defence lawyer (Art. 8 EPC) or a representative (Art. 42 EPC) may also appear on his/her behalf. Thirdly, the application may be submitted by the person closest to the convict who, in accordance with Art. 115, para. $11 \mathrm{EPC}$ - that is: a spouse, ascendant, descendant, siblings, kinship in the same line or degree, an adopted relative and their spouse, as well as a person living together.

The doctrine disputes the view that the closest person should also include friends of with the convict, because in the opinion of these authors this 
would mean the adoption of a widening interpretation that should not be used in the face of a legal interpretation of the term. ${ }^{19}$ The application may also be submitted by the superiors of the convicted person, which should be understood as officers and employees of the prison in which the convict is staying, and also persons who manage the convict's work or other activities in the field of their duties (Art. 72, para. 2 EPC).

\subsection{Criminological and social prognosis}

After submitting the application, the next step is to give an opinion in the form of a criminological and social prognosis [Lelental 2017, 571]. Criminological and social prognosis prepared for the period the convict stays outside the prison, consists of a written justification of the supposition that the convict during this stay will comply with the legal order. ${ }^{20}$ Para. 25, clause 2 of the above regulation by using the phrase "a forecast is made" indicates its obligatory nature. It is argued that a negative criminological and social prognosis is not a circumstance excluding the possibility of granting an authorization [Dąbkiewicz 2018, 639].

The above regulation indicates instead two groups of persons for whom there is no obligation to make a criminological and social forecast. The first of these are detained on remand who, in accordance with para. 28, sect. 1 of the above regulation - are exempt from this obligation. However persons detained referred to in Art. 139, para. 2 EPC, i.e. those detained on remand, who have the rights and obligations of convicts and who are serving a prison sentence, requiring the issuing of an ordinance on consent by the body at whose disposal they remain are still subject to the obligation to prepare a prognosis. The second group of people are the ones that are "punished," excluded from this obligation under para. 28 , sect. 2 of the above regulation.

${ }^{19}$ Ibid.

${ }^{20}$ Regulation of the Minister of Justice of 14 August 2003 on ways of conducting penitentiary interactions in prisons and detention centres, Journal of Laws No. 151, item 1469 , para. 25 , sect. 1 . 


\subsection{Conditional requirements for the possibility of obtaining an authorization}

Then, after submitting the application and its appraisal, it is necessary that at least one of the conditions that were articulated in Art. 141a EPC occurs. Premises for granting the permit from Art. 141a EPC correlate with the premises listed in the content of Art. 141, para. 1 EPC, although they do not only cover emergency and random events, but also planned events, e.g. birthdays, baptisms or funerals [Zgoliński 2018, 548].

The first of these concerns "visiting a seriously ill family member." It should be noted that, despite the fact that the Executive Penal Code does not contain a definition of a legal serious illness, it seems perfectly justified to adopt the view represented in criminal law, according to which the expressions used in the text of the Act should be interpreted in the semantic context given to them in everyday language, therefore it should be adopted, that "serious illness" is a life-threatening disease [Szczygieł 2013, 97]. It is indicated that the state of physical or mental health is also a circumstance within the meaning of Art. 141 EPC [Zgoliński 2018, 545]. However the state of health can only be determined by a doctor, which will make the doctor's opinion about the state of health of the person whom the convict wants to visit be important [Szczygieł 2013, 97]. In addition, it should be noted that a serious illness can only apply to a "family member," which should be understood as spouse, children, siblings and those who are related by affinity and kinship [ibid.].

The second condition concerns "participation in the funeral of a family member." According to the dictionary wording, a funeral is a "ritual accompanying the burial of the deceased" as well as a "funeral procession."21 Therefore, the nature of the rite, whether secular or religious, does not matter, or whether the Churches and religious associations organizing this ceremony have been entered in a specific register kept by the minister competent for religious denominations. The doctrine indicates that limiting the permit to attend a family member's funeral only, should be considered, as well as permission to visit only a seriously ill family member, to be too strict [ibid., 98]. The life situations of most convicts are complex, and many of them do not maintain contact with the family, which is why they are bound only by

\footnotetext{
${ }^{21}$ See https://sjp.pwn.pl/sjp/pogrzeb;2503307.html [accessed: 22.01.2020].
} 
formal considerations, while a large group of convicts remaining in informal relationships, in particular in a cohabitation, only maintains contact with them, thus depriving the person of visiting such a person when he is seriously ill or participating in his funeral, especially when these ties were permanent, is contrary to the principle of humanism [ibid.].

The last of the conditions expressed in Art. 141a EPC are "other cases of particular importance to the convict." This normative expression is an indefinite notion of an evaluative nature, which due to the principle of humanitarianism and respect for the dignity of the convict should be understood broadly [Dąbkiewicz 2018, 638]. The doctrine assumes that this concept should be interpreted as, on one hand, random events, and on the other, as cases related to the family and personal situation of the convict [ibid.].

Family circumstances do not apply to the convict directly and include not only the immediate family of the convict, but also the cohabitation in which he/she remained before detention in prison [Zgoliński 2018, 545]. However, the number of particularly justified cases relating to this condition cannot be determined [Lelental 2017, 569]. In turn, personal circumstances are directly related to the prisoner and include all circumstances causing "damage to the convicted person,” damage, injustice, disability [Zgoliński 2018, 545].

Examples of such situations are random accidents related to persons that are close to the convict, among which there are random accidents related to the convict's property, e.g. house or household fire, flood, or other cataclysm, as well as an important family event regarding the closest relatives of the convict, e.g. baptism, holy communion, child's wedding [Dąbkiewicz 2018, 638]. This concept also includes important events concerning the convict himself, e.g. the final exam, the need to participate in a significant property transaction [ibid.]. Therefore, as it can be seen, it is impossible to enumerate all circumstances that could fall into this enumerated concept, which is why the authorities that consider prisoners' applications play a major role.

\subsection{Ways of using the authorization}

The Act provides for three ways of using this type of permit to leave the prison, of which the first two are connected with convoy convicted by other entities ("Prison Officer" or "trustworthy person"), while the third way allows the convicted person to stay alone outside the penitentiary [Zgoliński 2018, 548]. About the need for a convoy or assistance, the assessment was left to 
the prison administration, because it is the administration that knows the convict and his/her inclinations best [Dąbkiewicz 2018, 638]. These methods are of significant importance, and the decision in this respect should comply with the principles of humane treatment of convicts and respect for their dignity (Art. 4, para. 1 EPC).

Granting a permit under the convoy of a Prison Service officer should be used in necessary cases, especially justified ones (e.g. for convicts posing a serious social threat, or for convicts towards whom it can be reasonably assumed that they will not return voluntarily to the prison) [Zgoliński 2018, 549].

A "trustworthy person" is, in turn, associated with trust on the part of the prison administration, and therefore it should be a person known to the administration, with appropriate characteristics and competence, the sum of which requires that he/she will guarantee the proper conduct of the convict outside the penitentiary, in particular that the convicted person will comply with the legal order [ibid., 548-49].

The doctrine indicates that the basic way of executing the permit should remain the convict's independent stay outside the penitentiary, while this method is not always possible to fulfil, because the consideration of the convicted person, especially his/her personal properties and conditions, sometimes requires that he/she should remain under convoy, and the convict's assistance should be optional at the same time [ibid., 548].

At the same time, it should be kept in mind that if the director of a penitentiary institution deems it necessary for the convict to remain under convoy or assistance during his release - he may refuse to use the permit granted to him/her in this form, because the convict's interest who doesn't want people participating in it, for example, in the funeral of a family member to learn that he is serving a prison sentence [Lelental 2017, 572]. I. Zgolinski also points to the interests of the convict, arguing that it is sufficient that he/she is not satisfied with the manner of exercising this permit [Zgoliński 2018, 548].

In addition, it should be noted that the consent to leave the penitentiary is given "for a period not exceeding 5 days," which indicates that the time spent outside the penitentiary is limited to the necessary minimum [Lelental $2017,572]$. One cannot agree with the view of S. Lelental, which indicates that it is unimaginable for a convoy or assistance to last for up to 5 days [ibid.]. This is possible, in particular taking into account the fact that the 
convict may - on the day of the funeral - stay in a completely different part of the country, which makes it impossible to cover such a distance in one day.

In the previously binding legal status, the convict in a penitentiary was granted the permit by a penitentiary judge [Dąbkiewicz 2018, 638]. From 1 January 2012, the authority to issue a decision was transferred to the director of a prison, which was justified by practical considerations, as a rule, the necessity to make decisions of this type occurs in urgent situations and is urgent [ibid.]. Before making a decision, the director must consider whether the convicted person may leave the penitentiary and thus whether he will not abuse the trust and use the release in a way that is intended for him [Zgoliński 2018, 549]. For this reason, it may be necessary to verify the circumstances justifying the release, as well as the analysis of the convict's personal files, although the kind and type of penitentiary in which the convict is detained is not insignificant, as well as the system in which the sentence is served, its amount and the time remaining in holding [ibid.].

\subsection{Granting permit vs temporary arrest and persons placed in a psychiatric plant}

The situation is slightly different in the case of a detainee who has the rights and obligations of a convicted person serving a prison sentence. According to Art. 141a, para. 3 EPC granting the permit requires the issuing of an ordinance of consent by the authority at whose disposal the detainee remains. This is dictated by the special status of the convicted person, against whom other criminal proceedings are pending in parallel, the outcome of which remains unknown [Zgoliński 2018, 549]. It cannot be ruled out that by remaining free, the convicted person could take steps to avoid or reduce his possible criminal liability [ibid.].

The situation is equally different in the case of persons placed in an appropriate psychiatric institution with basic security. Until the amendment from 2015, there was no statutory regulation that would provide for the possibility to grant perpetrators against whom a precautionary measure in the form of a stay in a psychiatric institution was granted, permission to temporarily leave the institution [Postulski 2016, 1277].

As it has already been articulated in this chapter, the authorization referred to in Art. 141a EPC does not include this group of people. In their case, Art. 204d EPC. Therefore, the possibility of granting the permit applies 
only to the perpetrator in a psychiatric institution organized as an institution with basic security conditions, which means that the authorization cannot be granted to a person in an institution with conditions of enhanced and maximum security [Osiński 2018, 770].

Permission for the offender's temporary stay outside the psychiatric institution is optional. It is an individual and specific legal act that settles the case of an individualized person, making it a decision within the meaning of Art. 7, para. 1 EPC [Postulski 2016, 1279].

Similarly as in the case of Art. 141a of the Penal Code, ${ }^{22}$ also in this case the procedure for granting the relief is of an application nature. The initiative to grant a permit for a temporary stay outside the institution may occur by the perpetrator, a member of his family, a trustworthy person or a doctor treating the person who is to use the permit [ibid.].

Obtaining a permit for temporary stay outside a psychiatric institution requires three conditions to be met simultaneously.

First of all, the entity obtaining the permit is obliged to be outside the establishment under the care of a family member or a trustworthy person. A trustworthy person referred to in Art. 204d, para. 1 EPC, is a person who: enjoys full civil and civil rights, has not been convicted of an intentional crime, has not been deprived of parental rights (one should properly speak of "parental authority") or guardianship, gives a guarantee of proper performance of duties, he/she is over 24 years old, and in exceptional cases 21 years old, if he/she has the qualifications or life experience indicating usefulness in conducting educational and resocialization activities. ${ }^{23}$ When granting the permit, the head of the psychiatric institution indicates the person who will look after the offender outside the institution, by name [ibid.].

Secondly, the granting of a pass must be justified by therapeutic or important family considerations, hence visiting a seriously ill family member or participating in the funeral of a family member falls within this area.

Thirdly, the danger that the offender staying outside the plant will commit a criminal act or threaten his own life or health is insignificant.

${ }^{22}$ Act of 6 June 1997, the Penal Code, Journal of Laws of 2020, item 568 as amended [henceforth cited as: PC].

${ }^{23}$ Regulation of the Prime Minister of 28 December 2016 on cooperation of entities in the execution of penalties, criminal, compensatory, protective, preventive and forfeiture measures, as well as social control over their implementation, Journal of Laws, item 2305 , para. 3. 
In accordance with Art. 204d, para. 2 EPC permission for a temporary stay outside a psychiatric institution is granted for a period not exceeding 3 days, and in exceptional, particularly justified cases, a permit may be granted for a period not exceeding 7 days. Determining the duration of stay outside the institution should be related to the reasons for granting the permit, i.e. to the purpose for which the permit was granted [Osiński 2018, 770].

Art. 204d, para. 3 EPC the permit is granted by the head of the establishment after obtaining the opinion of the attending physician, and that the head of the facility immediately informs the court of granting the permit. Although this provision does not set any requirements for an opinion, it should contain information on the current state of health of the offender and his behaviour [ibid., 770-71]. Moreover, this opinion should indicate compliance with the material requirements for granting a pass, but by its very nature does not bind the manager in making a decision on a pass. However he must obtain it before making it [Postulski 2016, 1279]. The negative position of the attending physician does not exclude the granting of a pass, however, it will undoubtedly affect the possible liability of a psychiatric institution in the event of damage by a vacationer [ibid.].

K. Dąbkiewicz claims that the court competent to adjudicate (Art. 199a EPC) does not have any authority to challenge the decision of the psychiatric establishment manager [Dąbkiewicz 2018, 860]. This author indicates that in this case it would be appropriate to inform first and foremost a penitentiary judge exercising penitentiary supervision who could exercise the rights provided for in Art. $34 \mathrm{EPC}$ [ibid.].

He is followed by K. Postulski, who indicates that the legislator's mistake is to introduce only the obligation to "inform the court" about granting the permit referred to in Art. 200c. As the court that has the power to decide on precautionary measures has no formal competence to interfere in the decision of the head of such a facility [Postulski 2016, 1280]. Such competences - resulting from penitentiary supervision institutions - are held only by a penitentiary judge, who may revoke such a decision pursuant to Art. $34 \mathrm{EPC}$, but the problem is, however, that he is not informed about the fact of issuing such a decision [ibid.].

Art. 204d, para. 2 EPC describing the actions to be taken in the event of the perpetrator's failure to return to the psychiatric institution after the expiry of the period for which the permit was granted, indicates that the 
court immediately orders his search and detention by the police and bringing him/her to the institution. The perpetrator is led by the police in the assistance of a doctor. Ordering the search and detention of the perpetrator is an organizational and administrative court act and is not subject to appeal review [ibid.]. K. Dąbkiewicz indicates that it should be assumed that the head of the psychiatric institution is also obliged to notify the court about the fact that the perpetrator did not return to the psychiatric institution despite the passage of time for which the pass was granted [Dąbkiewicz 2018, 860].

The consequences of the perpetrator's failure to return to the psychiatric institution after the period indicated in the permit is specified in Art. 204d, para. 5, which provides that the perpetrator may be re-authorized for a temporary stay outside the establishment not earlier than one year after the date of return to the establishment. On the other hand, in the case of a perpetrator staying outside a psychiatric institution who has committed a criminal act or has threatened his own life or health, the legislator indicates that in such a case he is not re-authorized for a temporary stay outside the institution (Art. 204d, para. 6 EPC).

\section{THE RIGHT TO SAY GOODBYE VS THE EUROPEAN PRISON RULES AND NELSON MANDELA RULES}

As already indicated in this article, the right to say goodbye - except for the Civil Code - is also based on the European Prison Rules and Nelson Mandela Rules.

The doctrine emphasizes that EPR mark a breakthrough in the approach to imprisonment, because they postulate its implementation in a way that from the beginning serves the social integration of the convict, and their significance goes beyond the framework of penitentiary policy, as they affect both criminal policy and social policy [Płatek 2008, 3]. EPRs emphasize that the punishment should be carried out in a way that from the first day serves the social reintegration of the prisoner, and the sine qua non condition is respecting the principle that imprisonment is the final measure and not routinely imposed [ibid., 7].

In addition, it is pointed out that although EPR are mere recommendations without binding force, belonging to the so-called soft law, they have 
a significant impact on the direction of prison reforms in Central and Eastern Europe, including Poland [Migdał and Skrobotowicz 2014, 110]. It seems that the most important regulations of the EPR are the convict's contacts with the outside world, which B. Gronowska classifies as a kind of penitentiary "classic," adding that it is one of the basic means of serving the so-called normalization of the prisoner's stay in the artificial world of penitentiary isolation, which raises a number of deprivations in the sphere of natural, psycho-physical human needs [Gronowska 2016, 10]. Moreover, according to this author, the issue of broadly understood family contacts always comes to the fore [ibid., 11].

The material legal basis for the right to say goodbye is Rule 24.7 EPR, which states that "whenever circumstances allow, the prisoner shall be authorized to leave the penitentiary either assisted or alone to visit a sick relative, attend a funeral or for other humanitarian reasons." Although the above regulation can see some common features of Art. 141a EPC, it remains, however, too high an indeterminacy, which is why it is only a kind of recommendation and interpretation guidance.

Similarly to EPR, also NMR do not have legally binding force for the countries to which they are addressed [Mrozek 2018, 173]. From an international law point of view, they represent the so-called soft law, i.e. non-legal law of formal legal bonds for individual countries, but a law creating only obligations in the moral-political sphere, without the need to implement traditional international procedures [ibid.].

Despite this, J. Nikołajew points out that the Minimum Rules are undoubtedly the United Nations model for lawful conduct against prisoners, and the use of the term "minimum" by the United Nations may indicate that the use of other than recommended solutions will violate the fundamental rights of prisoners during the prison sentence they are serving [Nikołajew 2013, 113-14].

As a side note, it should be noted that the European Prison Rules relate to the same issues, but are a proposal addressed to European countries, and both guidelines come from the common stem of ideological assumptions of the nineteenth century penitentiary congresses [ibid., 113].

Rule 70 of the NMR indicates that "a prisoner shall immediately report the death or serious illness of any close relative or partner. In the event of illness of a close relative or partner that is life-threatening, wherever circumstances allow, the prisoner should be allowed to visit the patient - 
escorted or alone - or to attend the funeral of a loved one or partner in the event of death." The above wording allows stating that - compared to Art. 141a EPC, as well as $24.7 \mathrm{EPR}$ rules - has a broader scope of subjects. As it has already been signalled, Art. 141a EPC refers to "family member" and EPR rule 24.7 covers "relative." NMR talk about a "close relative or partner," stating an extremely wide range of subjects and, at the same time, meeting socio-cultural changes.

In connection with the above, a de lege ferenda proposal seems justified, which assumes the amendment of the current Art. 141a EPC by replacing "family member" with "closest person." Then the person remaining in the same relationship (e.g. a partner) will fit into the concept of the closest person (Art. 115, para. $11 \mathrm{PC}$ ).

It should be noted, however, that the term "cohabitation" includes people who - regardless of their sex and age - live together, which implies running a shared household and (as it seems) a specific mental bond. ${ }^{24}$ The jurisprudence also indicates that contained in Art. 115, para. 11 PC the phrase "a person living together" defines a person who remains with another person in such an actual relationship in which there are simultaneously spiritual (emotional), physical and economic ties (shared household). Establishing the existence of such a relationship, i.e. "being in a relationship," is also possible when the lack of a certain type of relationship is objectively justified. The gender difference of people in such a relationship is not a condition for recognizing them as living together. ${ }^{25}$

To illustrate the situation regarding the granting of permits to leave the penitentiary, it should be noted that in 2018, pursuant to Art. 141a, para. $1 \mathrm{EPC}, 4106$ passes and permits were issued, of which 2739 were granted without assistance, 295 with the assistance of a trustworthy person, and 1072 under the convoy of a prison officer. ${ }^{26}$ As indicated by the Annual Statistical Information for 2018, 3407 people took advantage of these passes, of which 2,110 without assistance, 268 with the assistance of a trustworthy person, and 1,029 under convoy.

${ }^{24}$ Judgment of the Supreme Court of 21 March 2013, III KK 268/12, LEX no. 1311768.

${ }^{25}$ Resolution of the Supreme Court of 7 judges of 25 February 2016, I KZP 20/15, LEX no. 1984687.

${ }^{26}$ Ministry of Justice, Central Board of the Prison Service, Annual statistical information for 2018, https://www.sw.govspl/strona/statystyka-roczna [accessed: 22.01.2020]. 
In 2018, the number of detained, convicted and punished prisoners on average amounted to 74077 , which with 3407 persons obtaining passes indicates that approximately $4.5 \%$ of prisoners benefited from them pursuant to Art. 141a PC. Among these passes and permits there were 41 "late arrivals," which means the arbitrary extension of the time of the pass or permit that ended with a voluntary reporting no later than 24 hours after the set date of return. On the other hand, only 19 not returned, of which all concerned persons with a pass granted to leave alone, that is without assistance or convoy. For comparison, in 2017 pursuant to Art. 141a, para. $1 \mathrm{PC}, 4463$ passes and permits were issued, which means a decrease of approximately $8 \%$ compared to 2018 . It is puzzling that the number of permits granted to those that were detained on remand in both 2017 and 2018 was 0 . Thus, every twentieth inmate (less than $5 \%$ ) obtained permission to leave the penitentiary in accordance with Art. 141a PC. However, this does not mean that the pass system is defective, as their number is influenced by a number of different factors.

\section{GUARANTEES FOR THE RIGHT TO SAY GOODBYE}

There are three basic guarantees enabling the control of decisions issued by the director of a penitentiary institution regarding the permission of an inmate to leave the penitentiary in accordance with Art. 141a PC. The first guarantee is based on the possibility for the penitentiary judge to control the decision issued by the director of the penitentiary institution in the penitentiary supervision mode (Art. 34, para. $1 \mathrm{EPC}$ ). Then it is possible to control them under Art. 78, para. 2 EPC, as well as an appeal by a convict to a penitentiary court pursuant to Art. 7 EPC [Dąbkiewicz 2018, 639].

The first guarantee is mentioned in Art. 34, para. 1 EPC, which indicates that a penitentiary judge revokes an unlawful decision, inter alia director of a prison, if it concerns a person deprived of liberty. An "unlawful" decision should be understood as a decision that violates the provisions of the Executive Penal Code or another law, regulations issued on the basis of laws and for their implementation, directly applicable norms of the Polish Constitution and self-executing provisions of ratified international agreements [ibid., 184]. In other words, "contradiction with the law" occurs when the case is resolved in a specific individual case that violates the legal order 
in force in the Republic of Poland, with the sources of law specified in Art. 87, para. 1 of the Polish Constitution [Postulski 2018, 148].

Revocation of a decision that is unlawful comes by an order of a judge (J. Postulski indicates that revocation takes the form of a decision [ibid., $320]$ ), to which the convict and, among others, the director of a penitentiary institution is entitled to a complaint to the penitentiary court in whose district the decision was issued [Dąbkiewicz 2018, 185]. In addition, it should be noted that the "repeal" of a decision, as being contrary to the law, is the responsibility of the penitentiary judge, and not only its authorization, and that the penitentiary judge can only revoke the decision contrary to the law, but cannot change it [ibid.]. This leads to the conclusion that the revocation of the decision (regardless of its form of issue) is of a cassation nature [Postulski 2018, 148].

Second guarantee - related to Art. 78, para. 2 EPC - indicates that the General Director or district director of the Prison Service may give directors of prisons the instructions necessary for the correct and lawful execution of a prison sentence and the implementation of directions of rehabilitation work, as well as repeal decisions issued by them contrary to the law. Their revocation of the plant director's decision always takes the form of a decision and is subject to appeal to the penitentiary court pursuant to Art. 7 EPC, but only if the initial decision is subject to appeal, i.e. the decision of the director of the establishment [ibid., 612-13]. It is worth noting that the General Director or the district director of the Prison Service may not change decisions issued by directors of prisons, as their authority is limited only to repealing decisions that are contrary to the law [Lachowski 2018, 379].

The last guarantee includes the possibility of submitting a complaint to the penitentiary court. First of all, it should be noted that the disposition of Art. 141a, para. 5 EPC, indicating that a complaint may be lodged against the decision of the director of a prison facility is a statutory superfluum [Zgoliński 2018, 550]. Already Art. 7, para. 1 EPC indicates that the convicted person may appeal to the court inter alia decision of the director of a prison because of its unlawfulness, unless the law provides otherwise. Despite this, one should agree with the opinion that the positive effect of superfluum is the lack of room for a different interpretation, which is the case e.g. in Art. 140 EPC [ibid.].

Importantly, the subject of the complaint may only be the objection of unlawfulness of the decision - an act or other executive legal act and 
a provision of the Polish Constitution or a self-executing provision of an international agreement [Dąbkiewicz 2018, 73]. The complaint cannot be the subject of a complaint of non-compliance of the executive body's decisions with the recommendations contained in European Prison Rules, but it's an act of a character of a soft law, and therefore does not constitute sources of international law or executive criminal law, but only sets out the postulated range of penitentiary standards [ibid.].

The jurisprudence explicitly indicates that "[...] only the complaint of the convicted person alleging the unlawfulness of the individual legal act of the body of executive proceedings, which finally settles the issue concerning that convict, can be heard by the court on the principles set out in Art. 7 of the Executive Penal Code. ${ }^{27}$ In other words, in all cases in which the director of a penitentiary institution makes a decision affecting the rights and obligations of the convicted person, the implementation of the principle of subjective treatment of the convicted person (Art. 5, para. $1 \mathrm{EPC}$ ) requires admissibility to appeal such decisions to the court by a way of complaint [Lachowski 2018, 45].

The convicted person may challenge the decision in whole or in part, wherein he/she may also challenge the justification of the decision itself, but it is important for the applicant to have a gravamen (Art. 425, para. 3 of the Code of Criminal Procedure ${ }^{28}$ in connection with Art. 1, para. 2 EPC) [Dąbkiewicz 2018, 74] i.e. a subjective belief that the determination violates his rights or harms his interests.

The complaint may be lodged in writing or orally, with the protocol being written in the latter case [Lelental 2017, 64]. The complaint should indicate the contested decision or determination, as well as state what it the applicant is demanding, and if the complaint comes from a defence counsel or an attorney, it should also contain a justification [Dąbkiewicz 2018, 74].

The complaint shall be lodged with the authority that issued the contested decision within 7 days of announcement or delivery of the decision. Submission of a complaint after the expiry of this period makes it ineffective, unless the convicted person submits a request to restore the deadline - proving that this was due to reasons beyond his control - to the author-

${ }^{27}$ Order of the Court of Appeal in Wrocław of 31 August 2007, II AKzw 607/07, LEX no. 363749 .

${ }^{28}$ Act of 6 June 1997, the Criminal Procedure Code, Journal of Laws of 2020, item 30 as amended. 
ity that issued the contested decision [ibid., 75]. In the event of refusal to restore the time limit, a complaint may be submitted.

In a situation where a complaint is lodged directly with the competent court, that court will forward the complaint to the authority that issued it, and this will be done by way of a technical and organizational order [ibid.]. The complaint is relatively devolutive, which means that the body that issued it may accede to it [Postulski 2018, 118]. If the authority does not accede to the complaint, it shall forward it together with the files to the competent court without delay, which may suspend the execution of the contested decision [Dąbkiewicz 2018, 75].

The court with jurisdiction to hear a complaint about the decisions of the bodies listed in Art. 7, para. 1 EPC, in cases related to imprisonment, detention, order penalty, coercive measure resulting in deprivation of liberty, execution of a decision on conditional early release and a precautionary measure consisting in placing in a closed institution is a penitentiary court (Art. 7, para. $2 \mathrm{EPC}$ ) in which district's the convicted person is staying (Art. 3, para. $2 \mathrm{EPC}$ ) at the time of issuing the decision subject to appeal. ${ }^{29}$ When examining a complaint, the court rules in closed, one-manned session, and the decision of the court in the latter subject does not require justification, regardless of the type of decision [ibid., 76].

As a result of the examination of the complaint, three court decisions may be taken: up-keeping of the decision in force, annulment of the decision in whole or in part, amendment of the decision [Postulski 2018, 119]. What is worth emphasizing is the fact that during the examination of the complaint there is a ban on reformationis in peius, therefore the court will not be able to change the decision to the detriment of the convict in a situation where he/she was the entity initiating the proceedings, but the change can only occur in favour of the convict [Dąbkiewicz 2018, 75-76].

A similar case is the refusal of a psychiatric facility manager to permit a temporary stay outside the facility of a person staying in a psychiatric facility organized as having basic security conditions or to grant it for a shorter period than he applied for. It is emphasized that this refusal is a decision against which the perpetrator is entitled to lodge a complaint with the competent penitentiary court, pursuant to Art. 3, para. 2 EPC,

${ }^{29}$ Resolution of the Supreme Court of 7 judges of 18 December 2013, I KZP 18/13, LEX no. 1403594. 
which means that it must meet the requirements specified in Art. 7, para. 3 EPC [Postulski 2016, 1279-280].

Finally, it should be noted that Art. 141a, para. 4 requires that Art. 139, para. $8 \mathrm{EPC}$ was used accordingly. In practice, this means that the permit may be withdrawn, but only if certain circumstances occur, which is also a kind of guarantee. The first of these premises is the occurrence of new circumstances justifying the supposition that the convict during his stay outside the penitentiary will not comply with the legal order, and the second is the detention of the convicted person by an competent body in connection with his violation of the legal order.

"Justified guess" is less than "justified belief," because in this case one has to accept some risk of error that may result in the convict's behaviour during his detention, which must be treated as a failure, especially in the event of failure to return to the facility on time or the offender's commitment [Postulski 2016, 870]. The contradiction with the law - as it has already been articulated - is the non-compliance with the provisions of the Executive Penal Code or other act, ordinances issued on the basis of acts and for their implementation, directly applicable norms of the Polish Constitution and self-executing provisions of ratified international agreements [Dąbkiewicz 2018, 184]. K. Postulski points out that "legal order" should mean all prohibitions and orders arising from the provisions of criminal, administrative, civil, family, labour and other branches of law, as well as prohibitions and orders incumbent on the convict under the decisions of authorized bodies [Postulski 2016, 870].

The above regulation is a consequence of paying attention to the importance of the basic purpose of punishment, i.e. arousing the convict's will to cooperate in shaping his socially desirable attitudes, in particular the sense of responsibility and the need to comply with the legal order (Art. 67, para. 1 PC). It is pointed out that the attitude should be understood as the perpetrator's external relationship to the world around him, including the principles and legal order in force in society [Lachowski 2018, 359].

The current executive penal code has recognized the primary purpose of imprisonment as special prevention, which has in European penology a 200-year tradition that goes back to the concept of J. Bentham [Lelental 2017, 333]. However sufficient human and material resources are needed to achieve this goal [Krzeczek and Molis 2017, 138]. 


\section{CONCLUSION}

The fundamental conclusion drawn from these considerations is the indication that prisoners serving a prison sentence are entitled to say goodbye to their loved ones. However this is not an absolute right, since it is for the national authorities to assess each application on its essence.

Moreover, the right to say goodbye is not available to all categories of entities, since persons placed in a relevant psychiatric institution are deprived of this right. On the other hand, it seems doubtful to limit this right also to convicts posing a serious social threat, as no provision directly deprives them of them, which means that under the principle of lege non distinguente nec nostrum est distinguere it is not possible to deprive the right to say goodbye of this group of people.

Next, it is worth noting that the right to say goodbye comes not only from Polish law - including in the form of constitutional law and executive criminal law - but it is also based on normalizing international law, both in the form of hard law, i.e. the Convention for the Protection of Human Rights and Fundamental Freedoms, and soft law, i.e., European Prison Rules and Nelson Mandela Rules. In addition, the essence of the right to say goodbye includes two rights. The first is the possibility for a prisoner to attend a family member's funeral, while the second is the right to visit a seriously ill family member.

Finally, this work highlighted specific legal institutions to protect the right to say goodbye. The right to say goodbye guarantees include, first and foremost, the possibility for a penitentiary judge to review a decision issued by the director of a prison. Then, it is possible to issue the necessary instructions for the proper and lawful execution of a prison sentence and the implementation of rehabilitation directions, including the right to revoke decisions that are contrary to the law. Thirdly, there is the right of a convicted person to appeal a decision to a penitentiary court because of its unlawfulness.

This article highlights another very important aspect of the right to say goodbye. The possibility of taking part in saying goodbye to a family member helps to some extent prevent the phenomenon of prizonization, i.e. the process of human adaptation to prison conditions, consisting in the assimilation of prison culture, in particular the values, norms and behaviour patterns found in the prison community, and especially the informal norms 
of the prison subculture [Kuć 2015, 132-33]. The doctrine emphasizes that this "adaptation" is, however, negative, because its essence is the pursuit of "arranging one's life" in prison and not pursuing the maximum goal [Machel 2010, 179].

\section{REFERENCES}

Dąbkiewicz, Krzysztof. 2018. Executive Penal Code. Commentary. Ed. 4. Warszawa: Wolters Kluwer Polska.

Gołaczyński, Jacek, Jacek Mazurkiewicz, et al., ed. 2015. Non omnis moriar. Personal and property legal aspects of human death. Selected issues. Wrocław: Oficyna Prawnicza.

Gronowska, Bożena. 2016. "Long-term imprisonment vs respect for family life of convicts in the jurisprudence of the European Court of Human Rights." Prokuratura $i$ Prawo 4:5-21.

Hervada, Javier. 2011. “Obowiązki i prawa wiernych świeckich.” In Codex Iuris Canonici. Kodeks Prawa Kanonicznego. Komentarz. Powszechne i partykularne ustawodawstwo Kościoła katolickiego. Podstawowe akty polskiego prawa wyznaniowego. Edycja polska na podstawie wydania hiszpańskiego, ed. Piotr Majer, 215-22. Kraków: Wolters Kluwer Polska.

Jakuszewicz, Adam. 2015. "The issue of burials and deceased person's memory cult in the jurisprudence of the European Court of Human Rights." In Non omnis moriar. Personal and property legal aspects of human death. Selected issues, ed. Jacek Gołaczyński, Jacek Mazurkiewicz, Jarosław Turłukowski, et al, 342-63. Wrocław: Wydział Prawa, Administracji i Ekonomii Uniwersytetu Wrocławskiego. Oficyna Prawnicza.

Karska, Elżbieta, ed. 2013. Impact of the European Convention on Human Rights on human rights protection systems and international criminal and humanitarian law. Warszawa: Katedra Ochrony Praw Człowieka i Prawa Międzynarodowego Humanitarnego Uniwersytetu Kardynała Stefana Wyszyńskiego w Warszawie.

Krzeczek, Monika, and Katarzyna Molis. 2017. "A few words on the penalty - general approach." Studia Prawnicze. Rozprawy i Materiaty 1:133-40.

Kuć, Małgorzata. 2015. Lexicon of criminology. 100 basic concepts. Warszawa: Wydawnictwo C.H. Beck.

Lachowski, Jerzy, ed. 2018. Executive Penal Code. Commentary. Ed. 3. Warszawa: Wydawnictwo C.H. Beck.

Lelental, Stefan. 2017. Executive Penal Code. Commentary. Ed. 6. Warszawa: Wydawnictwo C.H. Beck.

Linowski, Krzysztof. 2001. "Possibilities of human development in conditions of penitentiary isolation by maintaining external contacts." Acta Scientifica Academiae Ostroviensis 8:125-43.

Machel, Henryk. 2010. "Penitentiary resocialization: the essence, terminological dilemmas, social sense, a few theoretical and staff comments." Resocjalizacja Polska (Polish Journal of Social Rehabilitation) 1:174-92.

Migdał, Jerzy, and Grzegorz Skrobotowicz. 2014. "Possibility of implementing the 2006 European Prison Rules regarding the reintegration model of imprisonment and the overpopulation of Polish penitentiary units." Roczniki Nauk Prawnych 24, no. 1:109-20. 
Mrozek, Kamila. 2018. "Nelson Mandela Rules.” Nowa Kodyfikacja Prawa Karnego 48:169-82.

Nikołajew, Jerzy. 2013. "Minimum Rules and the European Prison Rules vs the right of prisoners to freedom of conscience and religion in Poland." Studia z Prawa Wyznaniowego 16:111-35.

Nowicki, Marek A. 2017. Around the European Convention. Commentary on the European Convention on Human Rights. Ed. 6. Warszawa: Wolters Kluwer Polska.

Osiński, Leszek. 2018. "Commentary to Art. 204d." In Executive Penal Code. Commentary, ed. Jerzy Lachowski, 770. Warszawa: Wydawnictwo C.H. Beck.

Płatek, Monika. 2008. “2006 European Prison Rules.” Państwo i Prawo 2:3-17.

Postulski, Kazimierz. 2016. Executive Penal Code. Commentary. Ed. 6. Warszawa: Wolters Kluwer Polska.

Szczygieł, Grażyna B. 2013. Permits to leave the prison temporarily in the Polish penitentiary system. Białystok: Temida 2.

Śliwowski, Jerzy. 1984. "Abolitionist and extremely critical tendencies in penitentiary studies.” In Problemy współczesnej penitencjarystyki $w$ Polsce, vol. 1, ed. Brunon Hołyst, 5-30. Warszawa: Wydawnictwo Prawnicze.

Wedeł-Domaradzka, Agnieszka. 2016. "The right to contact family of persons arrested and serving a prison sentence - consideration of soft law standards and Art. 8 of the ECHR.” Polski Rocznik Praw Człowieka i Prawa Humanitarnego 7:301-18.

Wierzbicki, Piotr. 1984. "Contacts of convicts with the outside world and their importance in social re-adaptation.” In Problemy wspótczesnej penitencjarystyki w Polsce, vol. I, ed. Brunon Hołyst, 126-37. Warszawa: Wydawnictwo Prawnicze.

Zgoliński, Igor. 2018. "Commentary to the art. 141a." In Executive Penal Code. Comments, ed. Jerzy Lachowski, 545-50. Warszawa: Wydawnictwo C.H. Beck.

Zubik, Marek. 2007. "Subjects of constitutional freedoms, rights and obligations." Przegląd Legislacyjny 2:26-43.

\section{The Right to Say Goodbye and Permission to Leave a Penitentiary Facility}

\section{Summary}

This study discusses the right to say goodbye regarding the possibility of visiting seriously ill relatives and attending their funeral. Such a right shall apply for prisoners and is protected not only by Polish law, but also by international law, both in the form of hard law provisions, i.e. the European Convention for the Protection of Human Rights and Fundamental Freedoms, as well as soft law, i.e. European Prison Rules and Nelson Mandela Rules.

In this article we can find, the genesis of the right to say goodbye, which was presented by referring to individual judgments of the European Court of Human Rights. Following, the subjective scope of the right to say goodbye was articulated by indicating the authorized entities - who are beneficiaries of this right - and entities deprived of the possibility to use the permit to leave the prison. At the end, guarantees were emphasized to protect the entity against violations of the right to say goodbye.

Key words: Executive Penal Code; European Prison Rules; Nelson Mandela Rules; European Court of Human Rights 


\section{Prawo do pożegnania a zezwolenie na opuszczenie zakładu karnego}

\section{Streszczenie}

Niniejszy artykuł omawia prawo do pożegnania wyrażające się w możliwości odwiedzenia poważnie chorych osób bliskich, jak i wzięcia udziału w ich pogrzebie. Prawo to przysługuje w sposób szczególny osadzonym i jest chronione nie tylko przez przepisy prawa polskiego, lecz także międzynarodowego, zarówno w postaci przepisów hard law, tj. Europejską Konwencję o ochronie praw człowieka i podstawowych wolności, jak i soft law, tj. Europejskie Reguły Więzienne i Reguły Nelsona Mandeli.

W artykule tym odnajdziemy przede wszystkim genezę prawa do pożegnania, która została zaprezentowana poprzez odwołanie się do poszczególnych wyroków Europejskiego Trybunału Praw Człowieka. Następnie wyartykułowano zakres podmiotowy prawa do pożegnania poprzez wskazanie podmiotów uprawnionych - będących beneficjentami tego prawa - i podmioty pozbawione możliwości skorzystania z zezwolenia na opuszczenie zakładu karnego. Na zakończenie uwypuklono gwarancje mające na celu zabezpieczenie podmiotu przed naruszeniami prawa do pożegnania.

Słowa kluczowe: kodeks karny wykonawczy; Europejskie Reguły Więzienne; Reguły Nelsona Mandeli; Europejski Trybunał Praw Człowieka

Informacje o Autorze: MGR Dawid Niemczycki MSc, DoKToRANT - Uniwersytet Marii Curie-Skłodowskiej w Lublinie; adres do korespondencji: ul. Jana Kasprowicza 119C/75, 01-949 Warszawa, Polska; e-mail: dawidniemczycki@o2.pl; https://orcid.org/0000-00018176-3066 